\title{
Isolation of Arcobacter spp from the milk of dairy cows in Brazil
}

\author{
Isolamento de Arcobacter spp do leite de vacas leiteiras no Brasil
}

\author{
Celso Pianta1 ${ }^{1}$ Daniel Thompsen Passos ${ }^{2}$ Diego Hepp ${ }^{2}$ \\ Sérgio José de Oliveira ${ }^{1^{*}}$
}

\begin{abstract}
Bacteriologic examinations were performed on 188 milk samples collected from cows from 11 farms for diagnosis of mastitis in three cities of Rio Grande do Sul, Brazil. Among the common causes of mastitis, the most frequent isolates were Staphylococcus aureus, followed by Corynebacterium sp, Streptococcus uberis, Streptococcus dysgalactiae and Streptococcus agalactiae. Bacteriologic examination of 32 milk samples from one farm didn't show bacteria known as common etiologic agent of mastitis. Six samples of Arcobacter spp typed by genotypic tests as Arcobacter cryaerophilus (five strains) and Arcobacter butzleri (one strain) were isolated from cows milk of that farm. It is reported the isolation of Arcobacter species from the milk of cows in absence of clinical signs of mastitis. This is the first report of the detection of the microorganisms in the milk of dairy cows in Brazil. No previous reports are known from other countries.
\end{abstract}

Key words: Arcobacter spp, milk, dairy cows.

\section{RESUMO}

Foram realizados exames bacteriológicos em 188 amostras de leite colhidas de vacas de 11 propriedades leiteiras para diagnóstico de mastite, em três municípios no Rio Grande do Sul, Brasil. Entre as causas comuns de mastite, os isolados mais freqüentes foram Staphylococcus aureus, seguido de Corynebacterium sp, Streptococcus uberis, Streptococcus dysgalactiae e Streptococcus agalactiae. $O$ exame bacteriológico realizado em 32 amostras de leite de vacas de uma propriedade não demonstrou a presença de bactérias conhecidas como causadoras de mastite. Foram isoladas do leite de vacas desta propriedade seis amostras de Arcobacter spp, classificadas por testes moleculares como Arcobacter cryaerophilus (cinco amostras) e Arcobacter butzleri (uma amostra). É relatado o isolamento de espécies de Arcobacter do leite de vacas na ausência de sinais clínicos de mastite. Este é o primeiro relato da detecção dos microorganismos no leite de vacas leiteiras no Brasil.

Palavras-chave: Arcobacter spp, leite, vacas leiteiras.

\section{INTRODUCTION}

Arcobacter spp are bacteria displaying motility and morphology similar to the genus Campylobacter, but are aerotolerant and grow at $30^{\circ} \mathrm{C}$. Arcobacter butzleri, Arcobacter cryaerophilus and Arcobacter skirrowii have been recovered from humans and livestock. A. cryaerophilus have been isolated from aborted pig fetuses from some countries, including Brazil (SCHROEDER-TUCKER et al., 1996; OLIVEIRA et al., 1997; 1999). A. butzleri have been detected from enteritis in humans (LERNER et al., 1994; LAWERS et al., 1996; LAU et al., 2002; FERNANDEZ et al., 2004; VANDENBERG et al., 2004) and also the microorganisms were isolated from poultry and pig carcasses (RIDSDALE et al., 1998; OLIVEIRA et al., 2001; 2003).

Very little is the knowledge on the presence of Arcobacter spp in bovine. Mastitis in cows was reported by LOGAN et al. (1982). The authors infected animals with Arcobacter spp, demonstrating the pathogenicity to the mammary gland. The microorganisms have been detected in bovine feces (WESLEY et al., 2000; INGLIS \& KALISHUK, 2003).

\footnotetext{
ILaboratório de Bacteriologia e Micologia, Hospital Veterinário, Universidade Luterana do Brasil, ULBRA, Rua Farroupilha, 8001, Prédio 25, 92450.900, Canoas, RS, Brasil. E. mail: serjol@terra.com.br.*Autor para correspondência.

"Laboratório de Biotecnologia, Hospital Veterinário, ULBRA, Canoas, RS, Brasil.
} 
Also A. butzleri was isolated from $5 \%$ of the samples of bovine ground meat in an abattoir survey (ONGOR et al., 2004).

Taking into consideration the risks of infection to humans, this article reports the presence of Arcobacter species in samples of dairy cows' milk in suspected cases of mastitis.

\section{MATERIALS AND METHODS}

One hundred and eighty eight (188) milk samples were collected from dairy cows suspected of mastitis, from 11 farms in the state of Rio Grande do Sul, Brazil, respectively from the municipalities of Montenegro (1), Ibiraiaras (9) and Novo Hamburgo (1), for bacteriologic examination, as part of a research project on bovine mastitis. They were positive by California Mastitits Test (CMT).

Each sample was innoculated onto sheep blood agar plates and MacConkey agar. The plates were incubated aerobically 24 to 48 hours. Bacterial colonies were phenotipically characterized by biochemical tests (OLIVEIRA, 2000).

Each milk sample was also inoculated into liquid EMJH (Ellinghausen McCoulough Johnson and Harris - Difco) medium at a proportion of $1 \mathrm{~mL}$ to $9 \mathrm{~mL}$ of culture medium, for isolation of Arcobacter spp. Tubes were incubated about six days at $25-30^{\circ} \mathrm{C}$ under aerobic conditions. After this period it was used the STEELE \& MCDERMOTT (1984) membrane filter method, plating the inoculum onto sheep blood agar (brain heart infusion agar supplemented with 10\% defibrinated sheep blood). One drop of the growth from EMJH was filtered onto blood agar through a $0.45 \mu \mathrm{M}$ pore size cellulose acetate filter. The plates were left lids-up on the bench for about 30 minutes to dry and then inverted and incubated under aerobic conditions at $30^{\circ} \mathrm{C}$ for 2 days.

Suspect colonies on each plate were picked and checked by gram stain and inoculated into semisolid EMJH(0.15\% agar). Growths from semi-solid EMJH were examined under darkfield microscopy (40x magnification) for motile gram negative curved rods, as Arcobacter spp. Cultures were purified by streaking on blood agar and checked for oxidase, catalase and growth on MacConkey agar. Isolates were subcultured twice weekly into semi-solid BHI medium, waiting for genotypic tests.

Total DNA from each isolate characterized as Arcobacter spp was extracted according to the protocol developed by BOOM et al. (1990). Briefly, 100 $\mu$ l of culture were lysed in $900 \mu \mathrm{l}$ of a GuSCN buffer, the nucleic acid was bound to silica particles and washed twice with a GuSCN wash buffer and with a 70\% ethanol solution and once with acetone. The tubes were dried and the nucleic acids were released from the silica particles in $50 \mu \mathrm{l}$ of water and stored at $-20^{\circ} \mathrm{C}$.

The primer sequences were designed to amplify a 1202-bp fragment within the coding region of the 16S rRNA gene in Arcobacter species. The design was based on an alignment of the $16 \mathrm{~S}$ rRNA sequences of different Arcobacter species which demonstrated common conserved regions that served as targets for the primers. The forward and reverse primers used in this study were ARC-1: 5' - AGA GAT TAG CCT GTA TTG TAT C - 3' ARC-2: 5' - TAG CAT CCC CGC TTC GAA TGA - 3'. Specific primers for A. butzleri were ARC-5: 5'-TTC GCTTGC GCT GACAT-3' and ARC6: 5'CTATCC AGC GTA GAA GAT G -3', amplifying a 686 bp fragment from the gene 23S rRNA (HARMON \&WESLEY, 1996; OLIVEIRA et al., 2001).

The PCR reaction mixture contained $1 \mu \mathrm{l}$ of template DNA extracted from cultures, $1 \mu \mathrm{M}$ each primer, IX PCR Buffer, $1.5 \mathrm{mM} \mathrm{MgCl}_{2}, 200 \mu \mathrm{M}$ each deoxynucleotide, and $1 \mathrm{U}$ of Taq DNA polymerase in a total volume of $25 \mu \mathrm{l}$.

The PCR amplification was performed with an initial denaturation for $3 \mathrm{~min}$ at $94^{\circ} \mathrm{C}$, followed 30 amplification cycles, each consisting of $94^{\circ} \mathrm{C}$ for 60 seconds, $56^{\circ} \mathrm{C}$ for 60 seconds, and $72^{\circ} \mathrm{C}$ for 60 seconds to the primers ARC- 1 and ARC-2, and 40 cycles of $94^{\circ} \mathrm{C}$ for 20 seconds, $60^{\circ} \mathrm{C}$ for 40 seconds and $72^{\circ} \mathrm{C}$ for 60 seconds to the primers ARC-5 and ARC-6. A final extension at $72^{\circ} \mathrm{C}$ for 5 min was included.

Following amplification, amplification product of the primers ARC-1 and ARC-2 (genus specific) was digested with the enzyme $S s p 1$ to discriminate between the species $\boldsymbol{A}$. butzleri and $\boldsymbol{A}$. cryaerophilus on the basis of the fragments generated for the restriction. The digestion from the $\boldsymbol{A}$. butzleri samples forms fragments of 142, 358 and 701bp, while the $A$. cryaerophilus samples form fragments of 142 and 1060bp.

Products of the amplifications and digestion were visualized by $10.5 \%$ polyacrilamide gel electrophoresis and stained with silver nitrate (SANGUINETTI et al., 1994).

\section{RESULTS AND DISCUSSION}

Results of bacteriologic tests for identification of bacteria isolated from milk samples collected from 11 farms are summarized in table 1. As shown in table 1, among the common causes of mastitis, the most frequent isolate was Staphylococcus aureus, followed by Corynebacterium sp, Streptococcus

Ciência Rural, v.37, n.1, jan-fev, 2007. 
Table 1 - Results of bacteriologic tests in 188 milk samples from dairy cows from the municipalities of Montenegro, Ibiraiaras and Novo Hamburgo, state of Rio Grande do Sul, Brazil

\begin{tabular}{|c|c|c|c|c|}
\hline Isolate & Montenegro (70 samples) & Ibiraiaras (86 samples) & Novo Hamburgo (32 samples) & Total \\
\hline Staphylococcus aureus & 2 & 27 & 0 & 29 \\
\hline Streptococcus dysgalactiae & 4 & 7 & 0 & 11 \\
\hline Streptococcus uberis & 12 & 10 & 0 & 22 \\
\hline Streptococcus agalactiae & 7 & 0 & 0 & 7 \\
\hline Corynebacterium $s p$ & 19 & 7 & 0 & 26 \\
\hline Nocardia asteroides & 3 & 1 & 0 & 4 \\
\hline Arcobacter cryaerophilus & 0 & 0 & 5 & 5 \\
\hline Arcobacter butzleri & 0 & 0 & 1 & 1 \\
\hline Contaminants & 9 & 18 & 19 & 46 \\
\hline No growth & 14 & 16 & 7 & 37 \\
\hline
\end{tabular}

uberis, Streptococcus dysgalactie and Streptococcus agalactiae. Bacteriologic examination of $32 \mathrm{milk}$ samples from one farm didn't show bacteria known as common etiologic agent of mastitis. Six strains of Arcobacter spp, typed by genotypic tests as Arcobacter cryaerophilus (five strains) and Arcobacter butzleri (one strain), were isolated from the cows' milk of that farm.

This is the first report of the isolation of Arcobacter spp from milk samples of bovines. It is important also because they were the only microorganisms detected in the samples, there was absence of bacteria known as pathogenic to the mammary gland. The prevalence of Arcobacter in healthy beef or dairy cattle is unknown.

Arcobacter spp were present into the milk samples inspite of the absence of clinical signs of mastitis. In previous studies, there is only the report of LOGAN et al. (1982) on cases of isolation of Arcobacter in mastitis in cows. The authors infected the animals by intramammary inoculation and each infected quarter developed an acute clinical mastitis which resolved spontaneously after 120 hours. At the present work it is not possible to confirm the pathogenic effect on the mammary gland, but the occurrence of mastitis could be subclinical.

Arcobacter spp have been associated with cases of abortion in cattle (HIGGINS \& DEGRE, 1979), also isolated from preputial washing of a bull (GILL, 1988) and bovine feces (WESLEY et al., 2000). The present isolation of the microorganisms from milk enhances the difficulty to know how transmission occurs. Drinking contaminated water or untreated water is involved in transmission of $\boldsymbol{A}$. butzleri (RICE et al., 1998). A. butzleri was detected in this study in the milk from one cow and it means a potential risk as a human foodborne agent, causing enteritis (VANDENBERG et al., 2004).
Detection of Arcobacter in milk alerts for the need to avoid raw milk consumption and also the prevention of environmental contamination, adopting hygienic measures for cow milking. There is also the possibility of healthy carrier cows infecting their calves. The pathogenicity of Arcobacter spp to calves is unknown.

\section{CONCLUSION}

The isolation of Arcobacter cryaerophilus (5 samples) and Arcobacter butzleri (1 sample) from the milk of cows in absence of clinical signs of mastitis is reported. This is the first report of the detection of the microorganisms in milk in Brazil.

\section{ACKNOWLEDGEMENTS}

We are indebted to Jane Mendez Brasil and Vilson Benedito da Silva Junior from the Bacteriology Laboratory, and we thank Bruno Nunes Castro from Biotecnology Laboratory, Veterinary School, ULBRA University.

\section{REFERENCES}

BOOM, R. et al. Rapid and simple method for purification of nucleic acids. Journal of Clinical Microbiology, v.28, n.3, p.493-503, 1990.

FERNANDEZ, H. et al. Arcobacter butzleri an emerging enteropathogen: communication of two cases with chronic diarrhea. Brazilian Journal of Microbiology v.35, p.216218, 2004.

GILL, K.P.W. Aerotolerant Campylobacter strain isolated from a bovine preputial sheath washing. Veterinary Record, v.112, p.459, 1988

HARMON, K.M.; WESLEY, I.V. Identification of Arcobacter isolates by PCR. Letters Applied Microbiology, v.23, p.241244, 1996.

Ciência Rural, v.37, n.1, jan-fev, 2007. 
HIGGINS, R.; DEGRE, R. Spirillum-like organisms isolated from pig and bovine fetuses. Veterinary Record, v.104, p.559, 1979.

INGLIS, G.D.; KALISHUK, L.D. Use of PCR for direct detection of Campylobacter species in bovine feces. Applied and Environmental Microbiology, v.69, n.6, p.3435-3447, 2003.

LAU, S.K.P. et al. Identification by $16 \mathrm{~S}$ ribosomal RNA gene sequencing of Arcobacter butzleri bacteraemia in a patient with acute gangrenous appendicitis. Journal of Clinical Pathology: Molecular Pathology v.55, p.182-185, 2002.

LAWERS, S. et al. Arcobacter butzleri in the elderly in Belgium. In: NEWELL et al. Campylobacters, Helicobacters and related organisms. New York: Plenum, 1996. p.515-517.

LERNER, J. et al. Severe diarrhea associated with Arcobacter butzleri. European Journal Clinical Microbiological Infectious Diseases, v.13, p.660-662, 1994.

LOGAN, E.F. et al. Mastitis in dairy cows associated with an aerotolerant Campylobacter. Veterinary Record, v.110, p.229-230, 1982.

OLIVEIRA, S.J. DE et al. Classification of Arcobacter species isolated from aborted pig fetuses and sows with reproductive problems in Brazil. Veterinary Microbiology, v.57, p.347354, 1997.

OLIVEIRA, S.J. DE et al. Arcobacter cryaerophilus and Arcobacter butzleri isolated from preputial fluid of boars and fattening pigs in Brazil. Journal Veterinary Diagnostic Investigation, v.11, p.462-464, 1999.

OLIVEIRA, S.J. DE Microbiologia veterinária. Guia bacteriológico prático. 2.ed. Canoas: ULBRA, 2000. 240p.

OLIVEIRA, S.J. DE et al. Isolation of Arcobacter spp from poultry carcasses, in Brazil. Ciência Rural, v.31, n.4, p.639643, 2001.
OLIVEIRA, S.J. DE et al. Isolamento de Arcobacter butzleri de músculos de carcaças de suínos de terminação e matrizes descartadas abatidos em um matadouro no Estado do Rio Grande do Sul, Brasil. Ciência Rural, v.33, n.5, p.889-892, 2003.

ONGOR, H. et al. Investigation of arcobacters in meat and faecal samples of clinically healthy cattle in Turkey. Letters in Applied Microbiology, v.38, n.4, p.339, 2004.

RICE, W. E. et al. Isolation of Arcobacter spp from ground water. Letters Applied Microbiology, v. 28, p. 31-35, 1998.

RIDSDALE, J.A. et al. Prevalence of campylobacters and arcobacters in ducks at the abattoir. Journal Applied Microbiology, v.85, p.567-573, 1998.

SANGUINETTI, C.J. et al. Rapid silver staining and recovery of PCR products separated on polyacrylamide gels. Biotechniques, v.17, p.915-919, 1994.

SCHROEDER-TUCKER, L. et al. Phenotypic and ribosomal RNA characterization of Arcobacter species isolated from porcine aborted fetuses. Journal Veterinary Diagnostic Investigation, v.8, p.186-195, 1996.

STEELE, T.W.; MCDERMOTT, S.N. Technical note: the use of membrane filters applied directly to the surface of agar plates for the isolation of Campylobacter jejuni from feces. Pathology, v.16, p.263-265, 1984.

VANDENBERG, O. et al. Arcobacter species in humans. Emerging Infectious Diseases v.10, n.10, p. 1863-1867, 2004.

WESLEY, I.V. et al. Fecal shedding of Campylobacter and Arcobacter spp in dairy cattle. Applied and Environmental Microbiology, v.66, n.5, p.1994-1999, 2000. 